\title{
Overview and Challenges of Albanian Legislation under the New York Convenction (for Recognition and Enforcement of Foreign Arbitral Awards)
}

\author{
Rakel Muçaj \\ European University of Tirana \\ Email: rakel_mucaj2106@hotmail.com
}

Doi:10.5901/mjss.2014.v5n27p259

\begin{abstract}
In today's world, in the absence of supranational jurisdictions, international arbitration with its decisions, data from courts of arbitration, have served and will serve as an opportunity to restore credibility and integrity on the international economy. Recent years will mark a greater momentum on bilateral and multilateral agreements, as a real opportunity for foreign investors. Which invest despite political regimes or absence of jurisdictions in their countries? Among the most important conventions can be mentioned the New York Convention on the recognition and enforcement of foreign judgments. Without any doubts, it can be cited as the convention that has brought business cooperation relationships closer resulting in trust on the recognition of decisions in the most perfect way. As any current legislation, Albanian legislation is facing challenges and should reflect on its relations with foreign elements. Therefore, part of the discussion will be the opportunities and deficiencies of the Albanian legislation in comparison to the guidelines of the New York Convention.
\end{abstract}

Keywords: implementation, legislation, enforcement, jurisdictions.

\section{The Integration of the New York Convention in Albanian legislation}

The recognition and enforcement of foreign arbitral awards in the Republic of Albania are defined through two main instruments. For recognition and enforcement of arbitral awards shall apply the provisions of the Civil Procedure Code and the New York Convention. Regarding the Convention, the Republic of Albania has become part of the right of its interior through the accession process by determining that the instrument of accession is law. Albania has joined this Convention through the law nr.8688 dated 11/09/2000 "On the accession of the Republic of Albania to the "Convention on the recognition and enforcement of foreign arbitral decisions." Based on the constitution of the Republic of Albania, Article $116 / 1$ and 122/2, respectively, define the action of the convention and its legal power. After the ratification process its provisions become part of the internal legal system of our country, being implemented directly by having the priority over the laws of the country that do not agree with. As the above was determined in case of a conflict between norms of civil procedure and norms of the convention, the latter has priority (Brati, 2008).

Another instrument which governs the recognition and enforcement of foreign arbitral awards is the code of Civil Procedure (Note 1). The provisions of the code define as special trial the recognition of foreign arbitral awards. According to the Albanian legislation, court decisions of foreign countries are recognized and enforced in the Republic of Albania, in the conditions provided for in this Code or in special laws (Note 2). In the existence of special agreement between the Republic of Albania and foreign state, the provisions of the agreement are enforced (Note 3).

The Republic of Albania since joining the Convention undertakes the execution of foreign judgments in the territory of the Albanian state, recognizing and giving effect on their immediate implementation. The enforcement of foreign judgments follows a process of accreditation in the Albanian judicial authorities. A foreign arbitration decision during the process of accreditation on its binding effect of judicial authority, the applicability and power of recognition will be equated with an Albanian court decision. As a result, the arbitration decision which has come from the outside will be transformed into a court order (Brati 2008).

\section{The Legal Application of the Convention in the Spirit of the Albanian National Legislation}

The Convention on Recognition and Enforcement of Foreign Arbitral Decisions was founded in New York, on June the $10^{\text {th }}, 1958$ and entered into force on $7^{\text {th }}$ July the same year. Among the first countries that signed it were the USA, Belgium, Costa Rica and Germany. By 2013 the number of countries, which have acceded to, is 149. Our country has acceded to it through law nr.8688 of 09.11.2000: "On the accession of the Republic of Albania to the" Convention on 
Recognition and Enforcement of Foreign Arbitral Decisions". Since accession, the country has accepted a series of rights and obligations in order to adapt them to the right way possible. These obligations will now be internationally known.

This convention is based on two main principles that are: (i) the recognition and enforcement of foreign arbitral decisions, (ii) a reference to a court of arbitration (New York Arbitration convection, 2014). According to the first principle, it defines the application of the convention in its Article 1, which provides that for purposes of the consequences of recognition and enforcement, the arbitral decisions should be taken in a territory of a state other than the one where recognition and enforcement is required. The obligations of the contracting state for the recognition of arbitral awards will be implemented in accordance with the rules and procedures of the country where the decision is based (Note 4). Even in its Article 4, the convention stipulates that the party, which will address the court, must identify the decision of the arbitration and the arbitration agreement, where the agreement should be in accordance with Article 2 of the Convention. At the same time, the party against whom a lawsuit is filed is entitled to oppose the recognition and enforcement of decisions based on the prediction in the Convention (Note 5). However, it is the court which judge based on circumstances that the recognition and enforcement collide with Public Order Article 5/2. According to the second principle of the New York Convention it provides court referral for arbitration. It is exactly the Article II/3 which guides the cases where either the court of a Contracting State, submits a request for trial in cases where there is agreement between parties, the court shall, at the request of the parties to refer the case to parties involved for the arbitration process (Note 6)

Through the general principles of the Convention are set out the obligations arising in the Albanian Legislation to adapt the convention, which honor the essential requirements listed as below:

- The acknowledgment of implementation of the decisions of a foreign arbitration

- The jurisdictional exclusion of the courts

- The acknowledgment of arbitration agreements that are in accordance with the requirements of the Convention

- Rigorous Implementation of foreign arbitral awards

Following on the analysis mentioned above and for the fulfillment of obligations arising from the Convention, it is important that the legal nature of a foreign arbitral award is determined. According to the Convention, this decision should be taken outside the country where recognition and enforcement is required. In the context of the convention a foreign arbitral decision will be identified any decision taken outside the territory of the Republic of Albania, and its recognition and implementation will follow the acknowledgment procedure laid down in national legislation. In cases where the decision was taken within the territory of the Republic of Albania we are before an internal arbitration decision. The Code of Civil Procedure through its provisions sets the limits of the decisions. The article 400 of the Code of the Civil Procedure states that: "The provisions of this chapter apply to the arbitration procedure of trials, when participants in the process are domiciled or reside in the Republic of Albania and the place of arbitration procedure is located within its territory". However, two conditions must be met (a) the participant are resident in the Republic of Albania (2) and the place of arbitration procedure is based in the Republic of Albania. Article 400 of the Code of Civil Procedure is inevitably linked to Article 427 of the Code of Civil Procedure that underlines the obligation of the Albanian legislation to be implemented on these decisions. Based on these two articles and satisfying the two criteria mentioned above so that the parties are reside in the Albania and when the arbitration procedure is in Albania, all the provisions (Articles 400-438 Civil Procedure Code) will apply to all types of arbitration.

The Albanian legislation not only defines but also outlines the procedures to be followed during the process of acknowledgment. In certain cases, it may be that the parties are residing in the Republic of Albania and the arbitration place to be is in Albania, but require another procedure to be implemented on the agreement, so what will happen in such cases? In my studies on arbitration, it can be identified that some of its main advantages are: the freedom of the parties and their impact on the process, the right to select an arbitrator, procedures and applicable law. At the same time, the New York Convention that in terms of importance exceeds the internal legal norms determines the cases where the recognition and enforcement of a foreign arbitral awards can be refused. In Section 5/d of the convention is defined that: "the composition of the arbitral authority or the arbitral procedure was not in accordance with the agreement of the parties, or in the absent of such an agreement, it is not in accordance with the law of the country where it is settled. On the basis this article, is solidly accepted that the national law will apply in the absence of agreement, as the agreement constitutes the essence of the action on procedural approach. We currently require a revision of Article 427 of the Code of Civil Procedure and to leave the necessary space to the agreement of the parties in cases where they require a foreign legislation to be applied. It is important to mention the fact that the national legislation has defined international arbitration as a title in the Code of Civil Procedure but still today do not have a separate law that will define its regulation and implementation. 
The Albanian law recognizes and enforces foreign arbitral awards in two main stages:

a) The first phase is the application for recognition

b) The second phase is the review of the application by Court of Appeal.

\subsection{The application for recognition.}

A request for recognition and enforcement of foreign arbitral award is submitted to the court of appeal in the Republic of Albania, in the territory its execution is required. Unlike other countries' legislation, based on the Italian legislation (Note 7) that explicitly defines the territorial jurisdiction of the court. Requests can also be submitted through diplomatic channels when it is permitted by international agreements by applying the principle of reciprocity. In such cases, if the interested party has not appointed a representative he/she will be elected by the head of court of appeal, appointing a lawyer to submit a request (Note 8).

In addition, the Albanian legislation requires the validity of the request and the documents that must accompany it, such as: (i) a copy of a foreign arbitral award, translated into Albanian, (ii) confirmation of the arbitration forum that has issued the decision, stating that the decision has become final (III) attorney in cases where the issue will be represented by representatives, translated and notarized (Note 9). On a closer look to the documentation requirement we will see the lack of "arbitration agreement". A lack of such procedural means a deviation from the Convention, which explicitly requires its existence during the process of acknowledgment( Note 11). Such a prediction can be called a "procedural facilitation".

\subsection{Review of the application by the court of appeals}

According to the Albanian law, the Court of Appeal will not examine the issue of entirely, therefore the court is not interested on resolving the issue. However, it limits itself in controlling the decision whether or not the submitted one contains elements that make its implementation impossible. These are considered legal obstacles for the implementation of foreign arbitral awards (Note 12).

Foreign arbitral awards in the Republic of Albania are implemented only by the decision of the Court of Appeal, which empowers this arbitration decision and execution in accordance with the relevant civil procedural provisions (Note 13), as every Albanian judicial decision. In this way, the compulsory implementation of a foreign arbitral award will be nothing but a compulsory implementation of an Albanian judicial decision. In the absence of a positive decision by the Court of Appeal, a foreign arbitral award will not have any legal effect in the Republic of Albania and cannot be implemented.

\section{Problems on the Enforcement and Recognition of Foreign Arbitral Awards}

Firstly, at the end of the judicial process there will always have a decision on the issue in the trial. All legislations in the world primarily recognize the national court decisions and the flexibility of the execution of these decisions. Nowadays, the world's economy is represented by legal relations with foreign elements in them. Therefore, the enforcement of foreign judgments creates the "illusion" that a decision coming from abroad, obtained from a foreign judicial body, will affect the sovereignty of the state. In cases where the judgment is made in another state and the decision sought to be executed in another, will inevitably mean that we are dealing with an international treaty. As a result, I wanted to raise a question: "Does the recognition and enforcement of arbitral decisions on state sovereignty?

Categorically, arbitration does not affect the sovereignty of the state because an arbitration decision cannot be attributed to the role of sovereignty. It should be noted that arbitration as a process, always lies in the agreement of the parties, which defines arbitration as a way of resolving issues. Based on my studies on the arbitration process it is always expressed as a private process. During the application of the arbitration process its ultimate aim is simply providing the final decision. In any case should the arbitration decision force the execution of a decision because it will be affected by the national laws.

Secondly, another problem that affects the execution of the decision is the final moment when the parties seek recognition and enforcement of this decision. At this point, two important elements are defined: 1) the moment of recognition and execution parties are directed to the respective countries' legislation which can be called a paradox because the parties have selected arbitration in order to eliminate domestic jurisdiction. Next, these decisions should take effect from the national courts of the countries where recognition and enforcement is sought. This inevitably means that the parties will undergo court processes but the arbitration process was selected to avoid the ordinary courts and to 
process the case faster and easier.

Thirdly, in an analytical overview of the Albanian legislation precisely in article 399 of the C.C.P stipulates that: "The provisions of this chapter shall also apply for recognition of a final decision of the arbitration of foreign countries". At this point we know the Albanian legislation will similarly recognize the court decision as well as the arbitration decision, whether or not foreign. Obviously from the legal point of view, these two decisions have the same function but they differ essentially in the procedural aspect. A trial court procedurally cannot be equated with an arbitration decision. This is mainly because the arbitration process has a private character compared with the public character of a judicial process of the ordinary courts.

At this point, the Article 399 of the Code of Civil Procedure requires an interpretation because it does not clearly define if the application of this provision "for the recognition of foreign court decisions" shall be applied on a foreign arbitration award or for the recognition of foreign arbitration rulings these provisions should be applied to the extent that they do not conflict with the arbitration process features!

\section{Conclusions and Recommendations}

Reflections on the situation of convention assessed by Albanian legislation.

Firstly, I think that the current legal regulation that makes a group of provisions of Code of Civil Procedure is not fully appropriate concerning the recognition and enforcement of foreign arbitral awards in our state. One reason for this inadequacy could be the fact that the recognition and enforcement of foreign arbitral awards make reference to court decisions recognizing that foreign state. There is not a specific direct adjustment for the recognition of foreign arbitral awards. This way of regulation cannot be an optimal solution, even from the standpoint of formal legislative technique.

Secondly, if we would make a deep comparative treatment, it is noted that the provisions of the New York Convention are not fully in line with what provisions of Code of Civil Procedure foresee, concerning the recognition and enforcement of foreign arbitral awards. Despite the application of the general spirit of the New York Convention in some cases, procedural character inconsistencies are found between its provisions and procedure code. These discrepancies could create barriers through the judicial recognition of a foreign arbitral decision. That is why I judge their briefly documenting. Here we can mention as an example the case where the provisions of the Code of Civil Procedure do not require submission of "arbitration agreement", by the interested party, as a condition for the validity of the request for recognition, unlike the provisions of the Convention, which provides as mandatory the presentation of this agreement, in order to accept the request for recognition by the competent authority. But the provisions of the C.C.P predict the expression of the will of the parties to submit to arbitration authorities their disputes, as one of the legal requirements for recognition to be verified. Consequently, the lack of jurisdiction of the forum that granted the decision, which means unwillingness of the parties to resolve disputes in an arbitration process, is acknowledged by the Code as a legal barrier to indirect recognition of foreign arbitral award.

- The provisions of the Convention provide exactly the right and simultaneously, the burden of proof to the interested party to oppose the recognition and enforcement of foreign arbitral awards. They predict two specific cases where initiatives and the burden of proof belong to the competent authority. The provisions of the C.C.P make no such prediction. The construction of these provisions and the judicial practice in addition proves that despite claims of the concerned party opposing recognition- which, in one of the treated practice cases, did not take part in the sessions of litigation - the court of appeal itself controls whether the foreign arbitral award presented for recognition contains elements that constitute legal obstacles.

The provisions of the Code of Civil Procedure, predict that the decision of a foreign arbitration is not given force in the Republic of Albania, when a lawsuit is being reviewed by an Albanian court that is filed before the arbitration decision has taken a final form (Note 14). The comparative analysis made on the provisions of the Convention and the C.C.P reached the conclusion that such a prediction should not remain as a legal barrier to the recognition of a foreign arbitral award. This is mainly because this prediction exceeds the rejection limits of the acknowledgment provided by the New York Convention (Note 15). Conflicts with the obligation arising from the Convention to exclude the jurisdiction of the national court when the parties have entered into an arbitration agreement( note 16); it is regarded as a legal obstacle for a repeated acknowledgment( note 17), and moreover, such a prediction can be used as an artificial barrier, which would endanger the practical implementation of the Convention of New York.

What I feel important to mention about the problems of our legislation consists in fact in the necessity to overcome these deficiencies. This is achieved by carefully reading what is required by the Convention and analyzing models of implementation of the Convention in countries with consolidated experience in the field of arbitration, or in places with a past similar past in regard to the relationship with the Convention of New York. 
In addition, it must be admitted that a considerable part of the responsibility for the low level of performance that judicial practice in the field of recognition and enforcement of foreign arbitral awards, deficiencies attributed to internal legal regulations in this regard. Because of our system of law (written right), due to the short period that the New York Convention has been effective in our country, but because of the level of professionalism that characterizes the Albanian administration generally, it is not possible to fill in the gaps judicial practice that creates the legal framework. Fast approximation of the latter with international standards will bring a new spirit in the practice of decision-making that Albanian courts.

\section{Recommendations for a more Efficient Implementation of the New York Convention}

The implementation of the New York Convention would be at the right level in the Republic of Albania if it had a better legal framework and a practice court consolidated, in recognition and enforcement of decisions of international arbitration. For this purpose, primarily Albania needs quick amendment of legislation and for a contemporary approach towards its principles. The current regulation by the same provisions of the Code of Civil Procedure, the court's final decision of foreign countries and foreign arbitration, given the above argument is outdated and inadequate.

One possibility would be that the regulation of arbitration decisions to be made through legal norms, structured as provisions of a special law. A hypothetical law named for example: "Arbitration" or "Commercial Arbitration" could be the appropriate act that will consolidate the legal framework regulating the procedures of internal and international arbitration simultaneously. However, the provisions governing international arbitration and enforcement of its decisions, can be included as a separate part of the law "On Private International Law", an important law that is absent from our legislation.

\section{References}

Alban, B. (2008). Civil Procedure. Tirane: Duda

Code of Civil Procedure of Albania

Constitution of the Republic of Albania

Convention on the Recognition and Enforcement of Foreign Arbitral Awards (1958) - New York Convention

Italian Civil Procedure Code

Law no.8688 dated 09.11.2000 "On accession of the Republic of Albania in the "Convention on the Recognition And Enforcement of Foreign Arbitral Award

New York Arbitration Convection. (2014, 15 October) Summary of the text. Retrieved from new York Convention website: http://www.newyorkconvention.org/in-brief

Notes

Note 1. Code of Civil Procedure of Albania(C.C.P): Part II, Title III, Chapter IX "Recognition of judgments of foreign states". Art. 393-399.

Note 2. Article 393, par.1 C.C.P

Note 3. Article 393, par.2 C.C.P

Note 4. Article 3, of New York Convention

Note 5. Article 5 of New York Convention

Note 6. Article 2 (3) of New York Convention

Note 7. Article 8 of Italian Civil Code of Procedure

Note 8. Article 395 of C.C.P

Note 9. Article 395 of C.C.P

Note 10. Article 395 par. 2 of C.C.P

Note 11. Article 4(2) of New York Convention

Note 12. article 397 of C.C.P

Note 13.article 398 of C.C.P

Note 14. Article 394, par.4 of C.C.P

Note 15. Article 15 of New York Convention

Note 16. Article 2 (3) of New York Convention.

Note 17 article 394 (1) and (4) of C.C.P 